\title{
Geochemical evolution of laterites from two areas of the semiarid region in Bahia State, Brazil
}

\author{
Ilson Guimaraes Carvalho, Suely S.P. Mestrinho, Vanice M.S. Fontes, Om P. \\ Goel and Francisco de A. Souza \\ Department of Geochemistry, Instituto de Geociencias, Universidade Federal da Bahia, 40210 , \\ Salvador, Bahia, Brazil
}

(Received November 27, 1989; revised and accepted July 19, 1990)

\section{ABSTRACT}

Carvalho, I.G., Mestrinho, S.S.P., Fontes, V.M.S., Goel, O.P. and Souza, F.A., 1991. Geochemical evolution of laterites from two areas of the semiarid region in Bahia State, Brazil. In: A.W. Rose and P.M. Taufen (Editors), Geochemical Exploration 1989. J. Geochem. Explor., 40: 385-411.

Lateritic covers developed during the Pleistocene in two distinct areas (Gentio do Ouro District and Sento Sé) of the State of Bahia, Brazil, have been investigated geochemically. Samples of the bedrock (gabbros, from the Gentio do Ouro District, and silicate facies iron formation and associated iron-rich banded carbonates, from the Sento Sé Area) and the lateritic products (latosols, cuirasses and pisolites) were analyzed for major and selected trace elements ( $\mathrm{Co}, \mathrm{Cu}, \mathrm{Cr}, \mathrm{Ni}, \mathrm{V}, \mathrm{Pb}, \mathrm{Ba}, \mathrm{Au}$ and REE). The purpose of the research was to study the geochemical evolution of the laterites and the relationship of weathering processes to secondary gold mineralization.

Four types of element mobilities are recognized, defined by progressive depletion (type A) or enrichment (type $C$ ) in the sequence latosol-cuirasse-pisolite or by extreme enrichment (type B) or depletion (type $\mathrm{D}$ ) in the cuirasse. $\mathrm{Cr}$ and $\mathrm{V}$ have similar behavior (type $\mathrm{C}$ ), whatever the type of parent rock; however, when the original rocks are gabbros, $\mathrm{Co}, \mathrm{Cu}$ and $\mathrm{Ni}$ demonstrate behavior $\mathrm{A}, \mathrm{B}$ and A, respectively. Also Ti has the same type of mobility (type A), whatever the type of parent rock.

The concentrations of some residual elements, e.g., Ti, V, Mn, Fe and Au, are inherited from the original rocks, that is, they exhibit higher values in the lateritic materials on parent rocks in which their contents are high.

The enrichment of REE in the lateritic materials on iron-rich carbonates is attributed to relatively basic and reducing conditions at depth. This environment allowed the ions of these elements ( $\mathrm{Ce}$, $\mathrm{Sm}, \mathrm{Eu}$ and $\mathrm{Yb}$ in the reduced ionic form) to stay in solution along with $\mathrm{Fe}^{2+}$. At shallow depth, under oxidizing conditions, the iron oxyhydroxides adsorbed the REE ions. This adsorption was more effective for $\mathrm{La}, \mathrm{Ce}$ and $\mathrm{Yb}$ ions.

The REE contents in the lateritic products from gabbros indicate a depletion of HREE plus Eu. Nd and $\mathrm{Sm}$ are also depleted in cuirasses and Ce is depleted in pisolites. The loss of these REE and the slight concentration of LREE in the red latosol of the Gentio do Ouro District are attributed to partial leaching of REE by a relatively acidic solution. The adsorption of REE by iron oxyhydroxides was less intense here than in the weathering of the iron-rich carbonates at Sento Sé Area. It was also more effective for $\mathrm{La}$ and $\mathrm{Ce}$ (ions). This type of weathering solution may be generated from oxidation of the accessory pyrite present in the gabbros of the Gentio do Ouro District. It may dissolve primary gold which then precipitates on encountering basic conditions at depth. 


\section{INTRODUCTION}

Geochemical research into primary and secondary gold in iron-rich laterites has increased substantially in recent years. This paper presents a geochemical study of the evolution of laterite and its relationship to secondary gold in the Gentio do Ouro District and Sento Sé Area of Brazil. The climate of the region is semiarid. Tricart and Da Silva (1968) suggest that the climate was humid-tropical during the Tertiary and that it graded into the present semiarid conditions. Economic concentrations of secondary gold are only reported to occur in the Gentio do Ouro District.

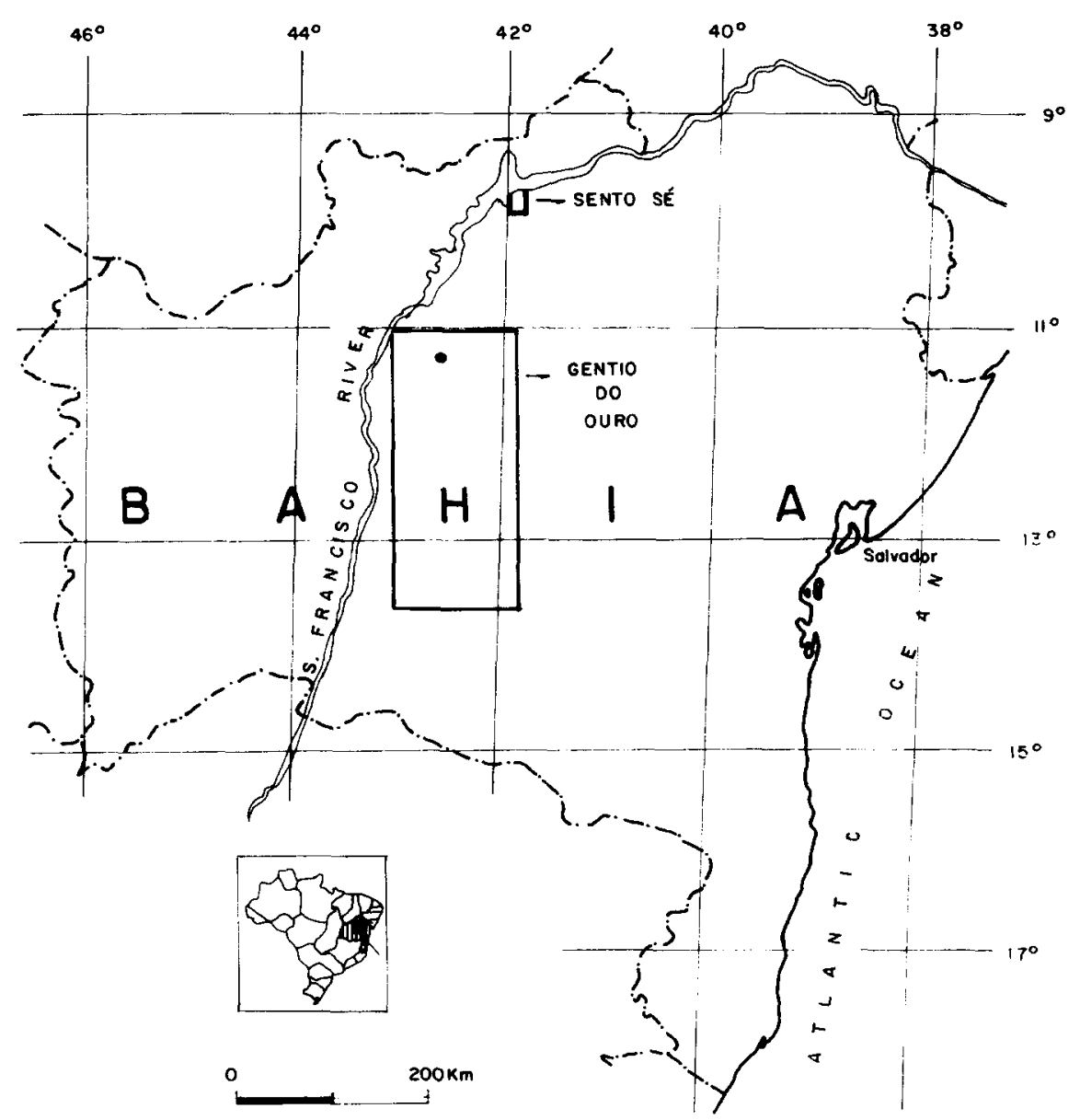

Fig. 1. Location of the investigated areas. 


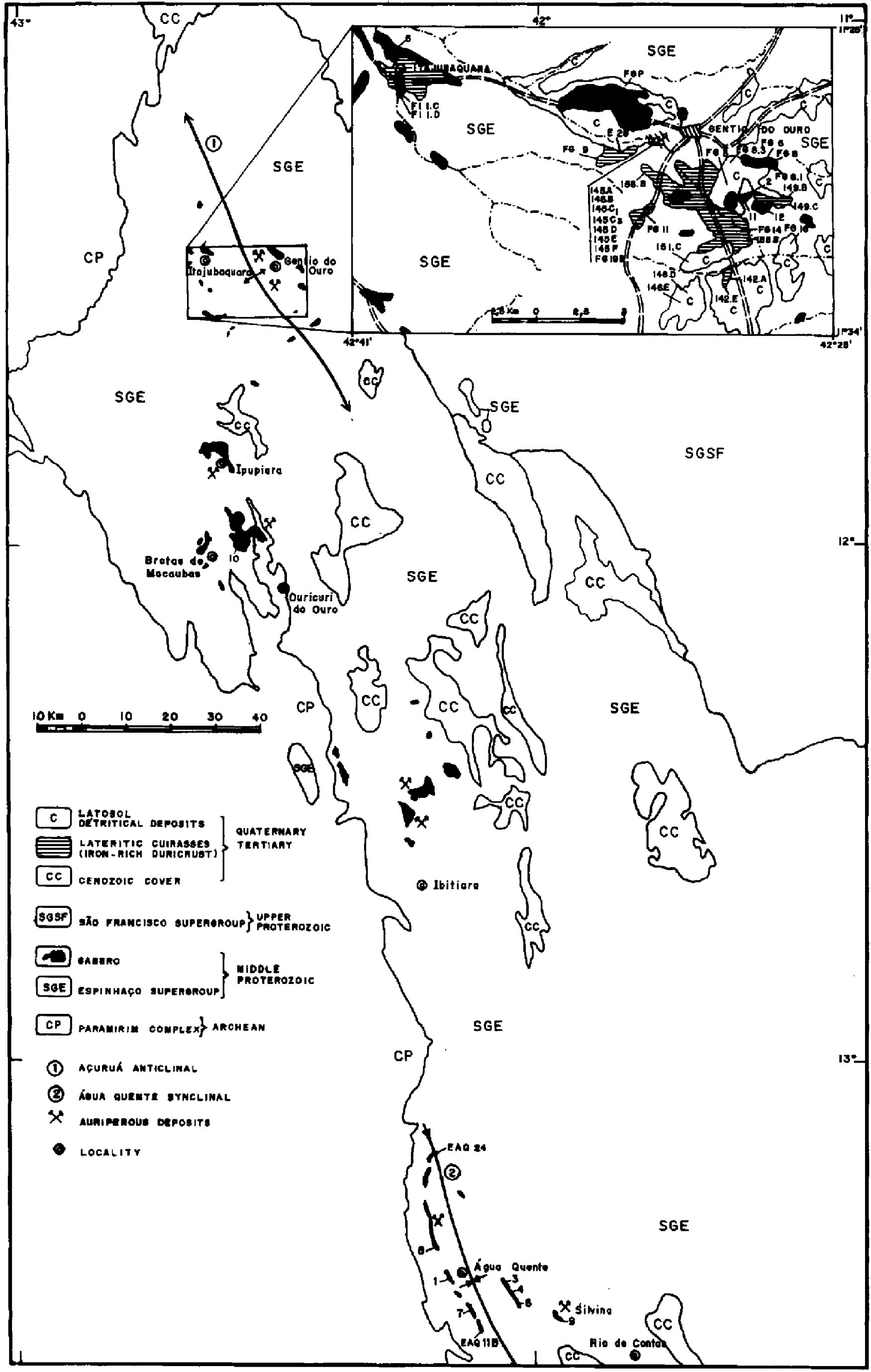

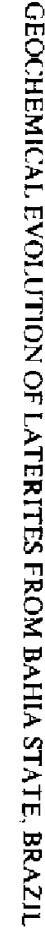

Fig. 2. Distribution of gabbroic rocks and sample locations in the Chapada Diamantina Occidental Area. 


\section{GEOLOGICAL SETTING}

\section{The Gentio do Ouro District}

The Gentio do Ouro District is situated in the central part of Bahia State (Fig. 1). Gold has been produced from this region for more than a hundred years. Since 1981 detailed geological studies have been carried out by Carvalho $(1984,1985,1986)$ and Carvalho et al. $(1987,1988)$. Primary gold mineralization is related to metasomatic and hydrothermal phenomena caused by the intrusion of a tholeiitic mafic magma which generated sill-like bodies of gabbros. These sills are interlayered in the mostly metasedimentary sequence of the lower part of the Espinhaco Supergroup (Fig. 2). The contact between the gabbros and the host stratigraphic sequence is characterized by metasomatic alteration zones where intense ferruginization and silicification took place. Lenticular concentrations of quartz which range from a few centimeters to six meters in width occur in these contact zones. The contact zones also contain ferruginous metasandstone, a hybrid type of metasandstone and gabbro, thin iron oxide horizons, quartzites, iron-rich hornfels derived from clayey metasiltite, and a quartz-kaolinite material which results from alteration of rare anorthositic zones of the basic intrusion. Because the hydrothermal-metasomatic processes were not homogeneous throughout the contact zone, only the quartz lenses and the ferrugineous metasedimentary rocks are frequently observed at exposures of the contact. Primary gold occurs mainly in the quartz lenses, and sulfides consist mostly of disseminated accessory pyrite $(1-2 \%)$ and traces of chalcopyrite in the gabbros at the contact zone.

The regolith on the mafic and subordinate iron-rich metasedimentary rocks is typified by a brown saprolitic horizon (C-horizon) $(0-30 \mathrm{~cm}$ in thickness) overlain by red latosols (B-horizon) (up to $15 \mathrm{~m}$ thick) with iron-rich duricrusts (cuirasses) (0-3 m in thickness) on top. Under the present semiaridic conditions the instability of this profile is shown by the decay of the cuirasse into pisolites and intense erosion affecting both cuirasse and latosol.

The primary gold participated in this weathering process and was remobilized and reconcentrated to economic and subeconomic levels in the lateritic products (Table 4a). Carvalho (1985) studied this form of gold occurrence and concluded that the supergene enrichment is characterized by both increase in gold fineness and growth of gold nuggets. Microscopic colloform gold was reported by Carvalho $(1984,1985)$ in the concentric Fe-oxyhydroxide-hematitic bands of pisolites. Similar textures and botryoidal and dendritic gold may be visible to the naked eye in the cuirasses. Spherical, botryoidal and dendritic gold nuggets which are rarely larger than $0.5 \mathrm{~cm}$ in diameter are found in the red latosol. Ancient prospectors reported the occurrence of gold nuggets weighing up to $1.0 \mathrm{~kg}$ in the red latosol.

Exploration for both primary and secondary gold uses a primitive method 


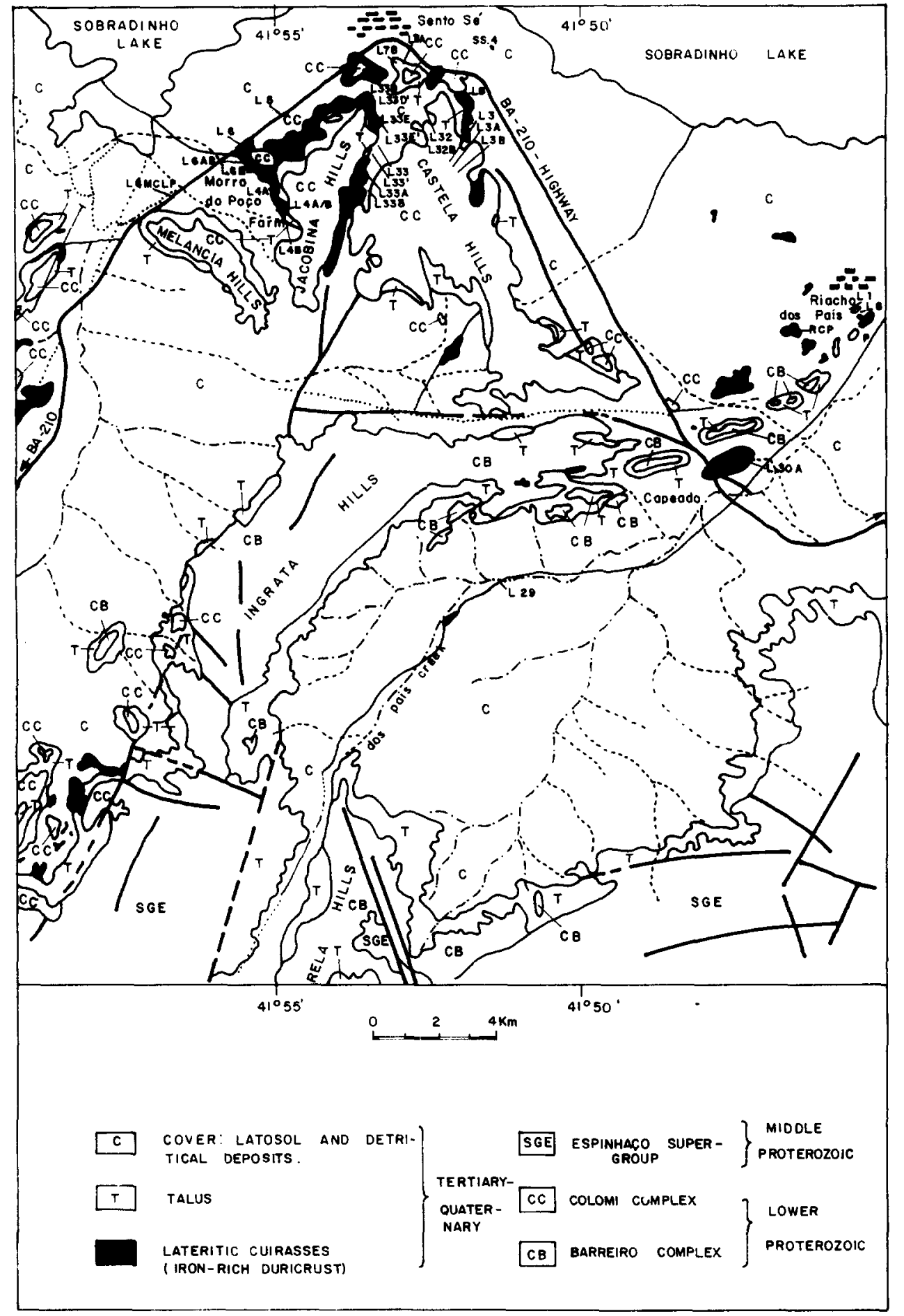

Fig. 3. Geological map and sample locations, Sento Sé area. 
which is locally termed "garimpagem". This includes breaking blocks of gabbros, quartz lenses, hornfels and cuirasses, grinding of these materials plus pisolites, followed by sifting (sieving) and concentration by panning. The latosol is subjected to the latter treatment. Gold nuggets are either searched for in the panning concentrate or recovered in a slide sluice mechanism termed "mufula" that uses air blown down the slide. All these procedures are performed dry because of the scarcity of water in the region. The Garimpo do Gaucho is the sole mine that uses water (wellwater from drill hole) in ore treatment. It was set up in 1985 and also treats waste from the other works to recover small gold particles by amalgamation.

\section{The Sento Sé Area}

The Sento Sé Area is north of Gentio do Ouro District (Fig. 1). It is underlain by a sequence of volcano-sedimentary rocks (Colomi-Barreiro Complex ) that includes quartzite, coarse metarkoses, phyllites, tuffaceous metasandstones, acid and basic metavolcanic rocks and metamorphosed chemical sediments. The latter included banded iron formation, characterized by the presence of oxide (quartz-rich vs. magnetite-hematite-rich bands) and silicate (amphibole-magnetite-rich vs. magnetite-rich bands) facies in association with metachert and banded iron-rich magnesian carbonates (calcite-dolomite-magnesite-amphibole-rich vs. quartz-carbonate-rich bands). Metasedimentary rocks, mostly quartzites, metasandstones and minor metapelites and metaconglomerates (Chapada Diamantina Group) occur in the southern part of the studied area (Fig. 3). There is no record of primary gold occurrence, although gold concentrations in the siliceous metatuff are locally up to 31 ppm(!) (Teixeira, 1989).

During the early stages of more humid conditions (Pliocene), weathering of the metamorphic rocks developed a lateritic cover which consisted mostly of red and brown latosols. With the gradual onset of more arid conditions, a duricrust (cuirasses) developed on the latosols over the iron-rich metasedimentary rocks. Under the present climatic conditions these cuirasses are decaying into pisolites (Carvalho, 1984, 1985, 1988). The cuirasses in this area are thicker (up to $6 \mathrm{~m}$ ) than those reported in the "Gentio do Ouro Model".

\section{SAMPLING, ANALYSES AND PRESENTATION OF DATA}

Forty-six samples from the Gentio do Ouro District plus 30 samples from the Sento Sé area were selected and analysed as indicated in Tables 1-3.

The major elements expressed as oxides $\left(\mathrm{TiO}_{2}, \mathrm{Al}_{2} \mathrm{O}, \mathrm{CaO}, \mathrm{MgO}, \mathrm{MnO}\right.$, $\mathrm{Fe}_{2} \mathrm{O}_{3}$ (as total iron ), $\mathrm{Na}_{2} \mathrm{O}$ and $\mathrm{K}_{2} \mathrm{O}$ ) and the trace elements $(\mathrm{Co}, \mathrm{Cu}, \mathrm{Cr}$, $\mathrm{Ni}, \mathrm{V}, \mathrm{Pb}, \mathrm{Ba}$ and $\mathrm{Au}$ ) were determined by atomic absorption in the laboratories of the Geochemistry Department, Universidade Federal de Bahia, Bra- 


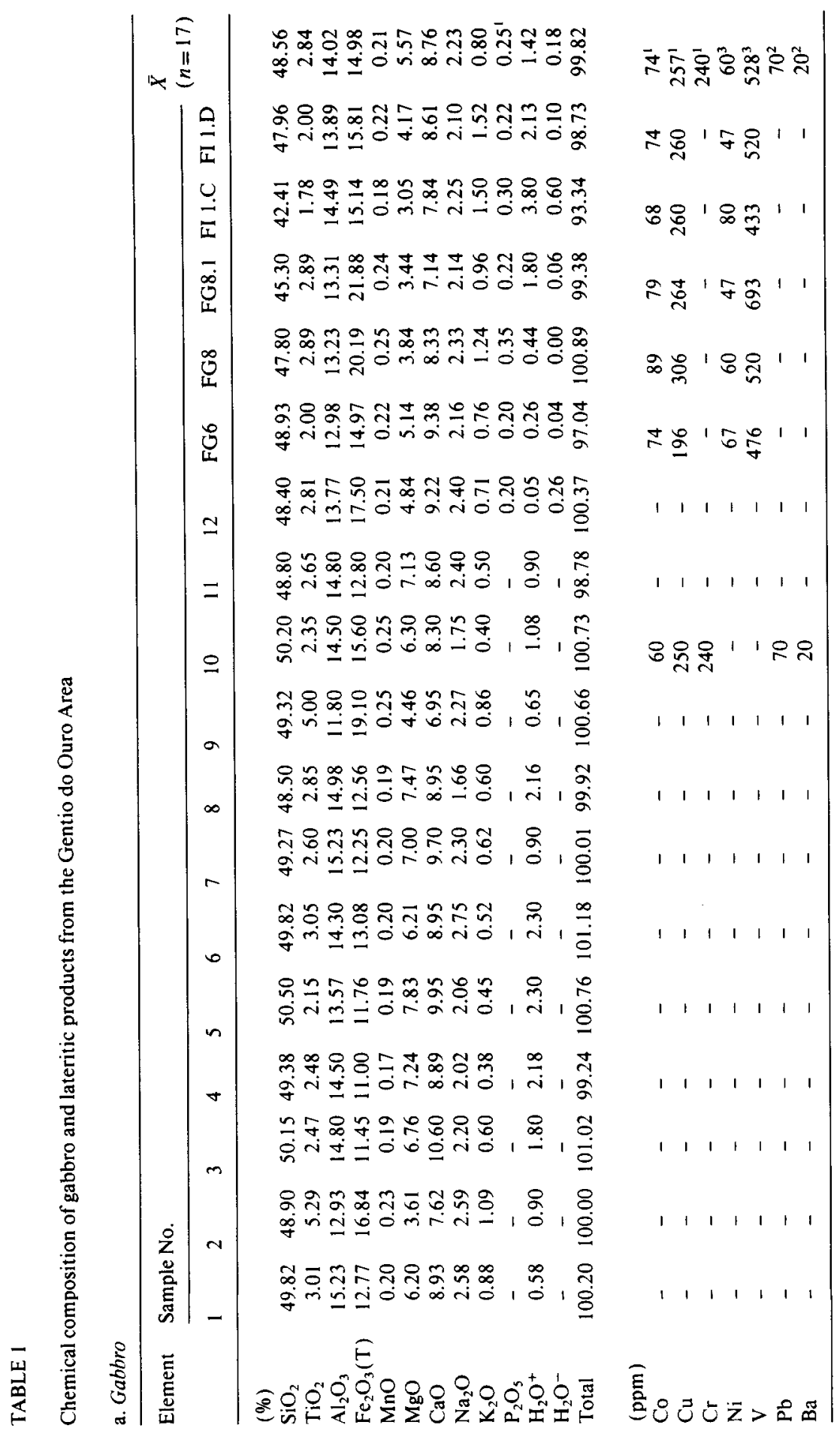




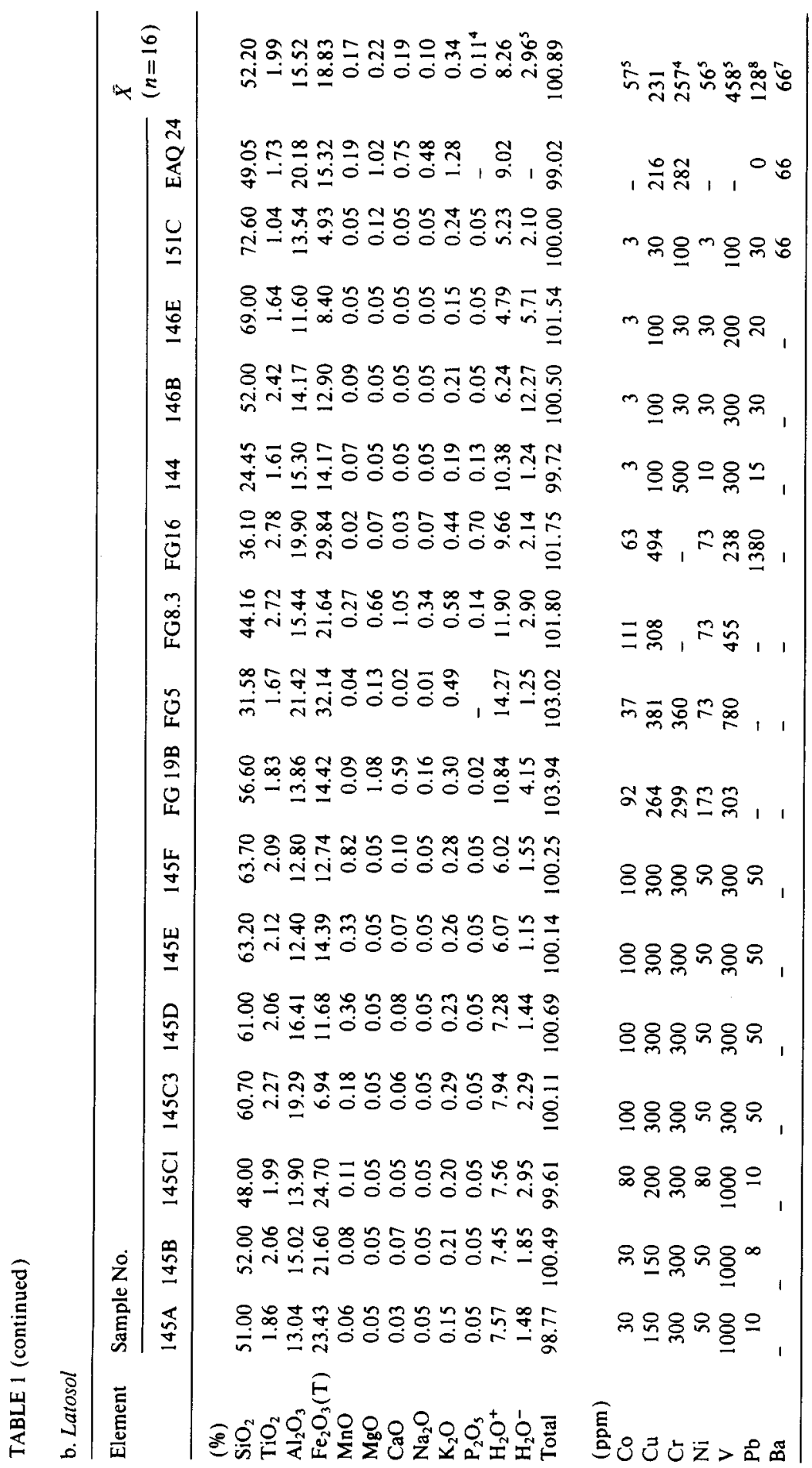




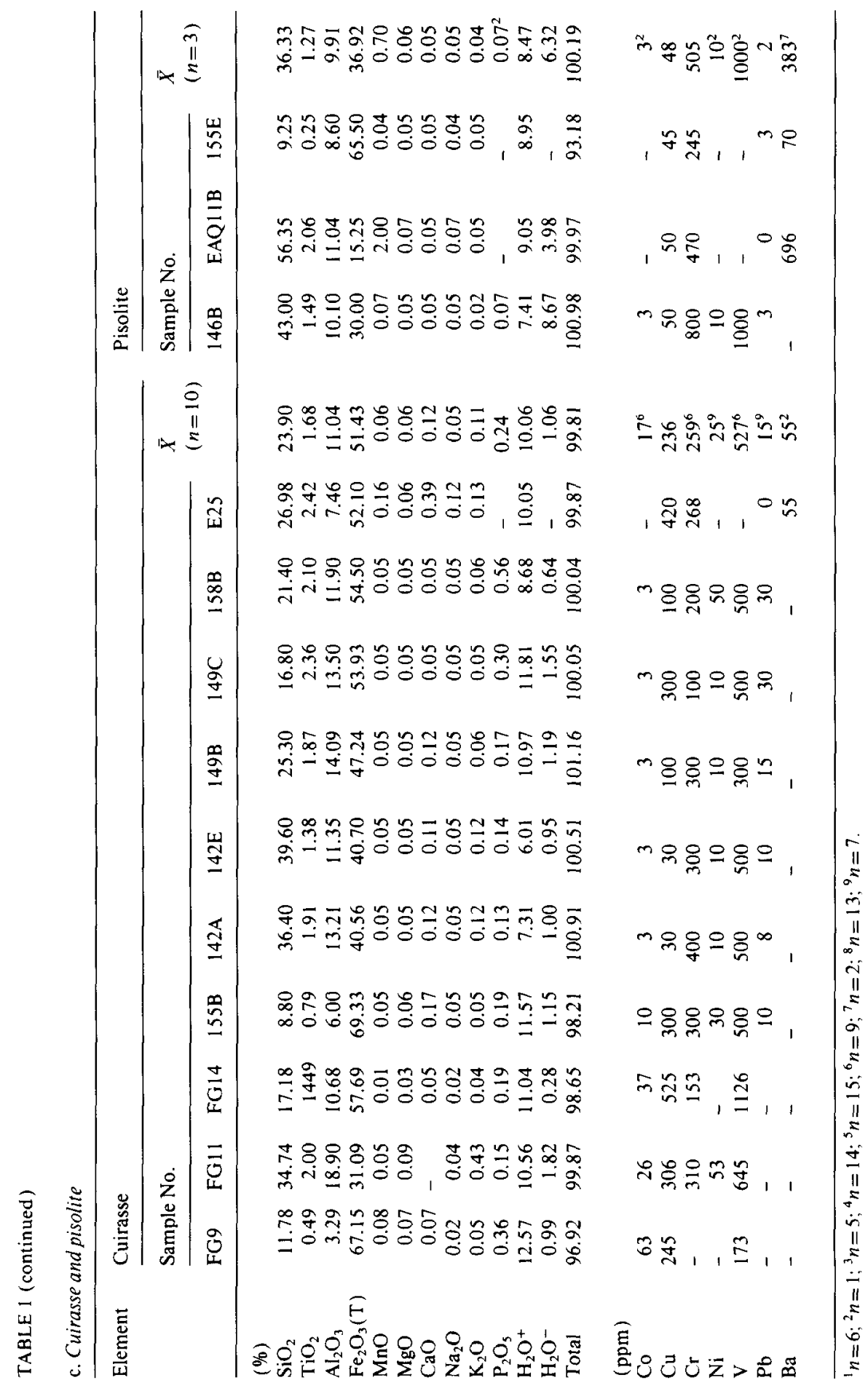




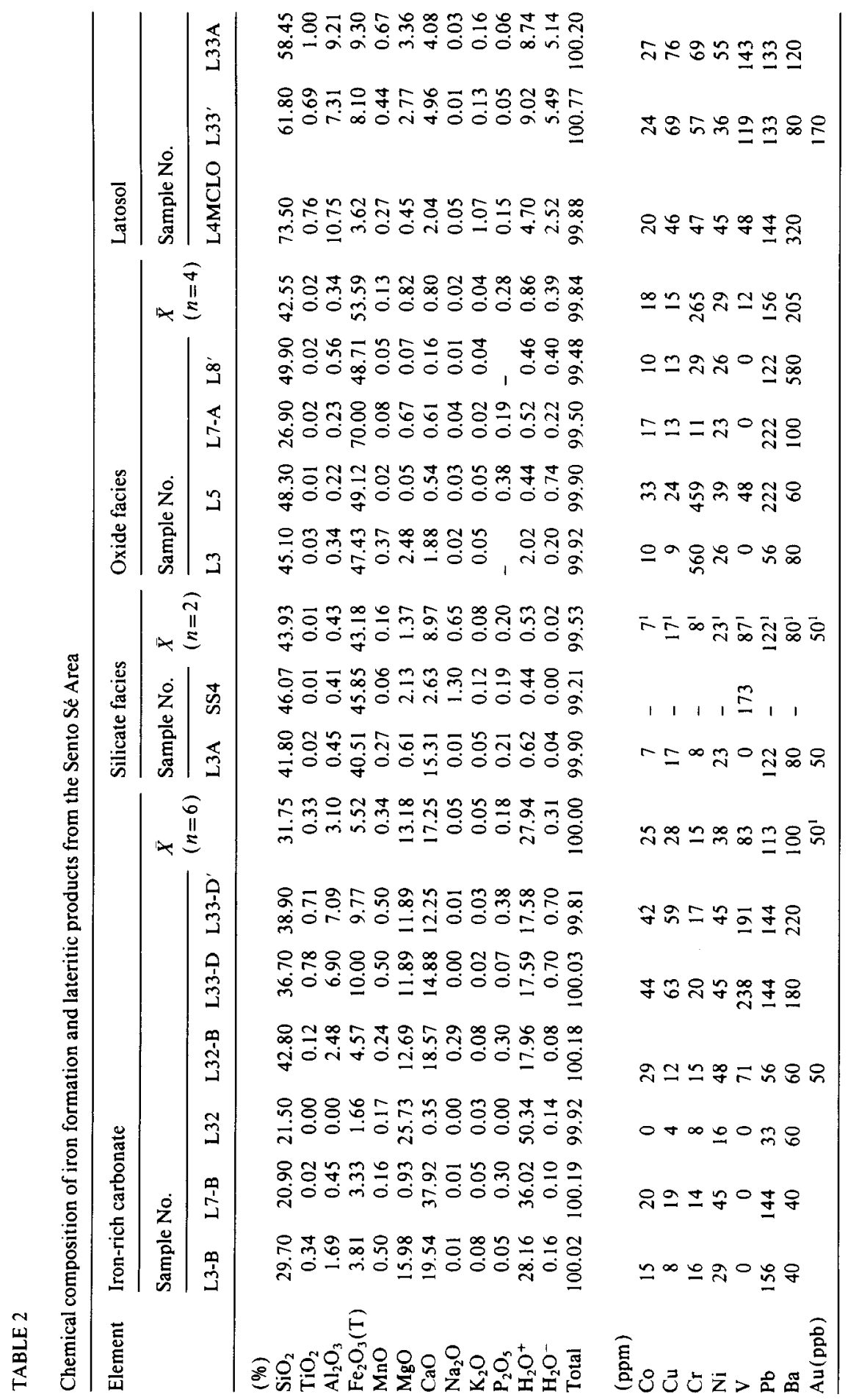




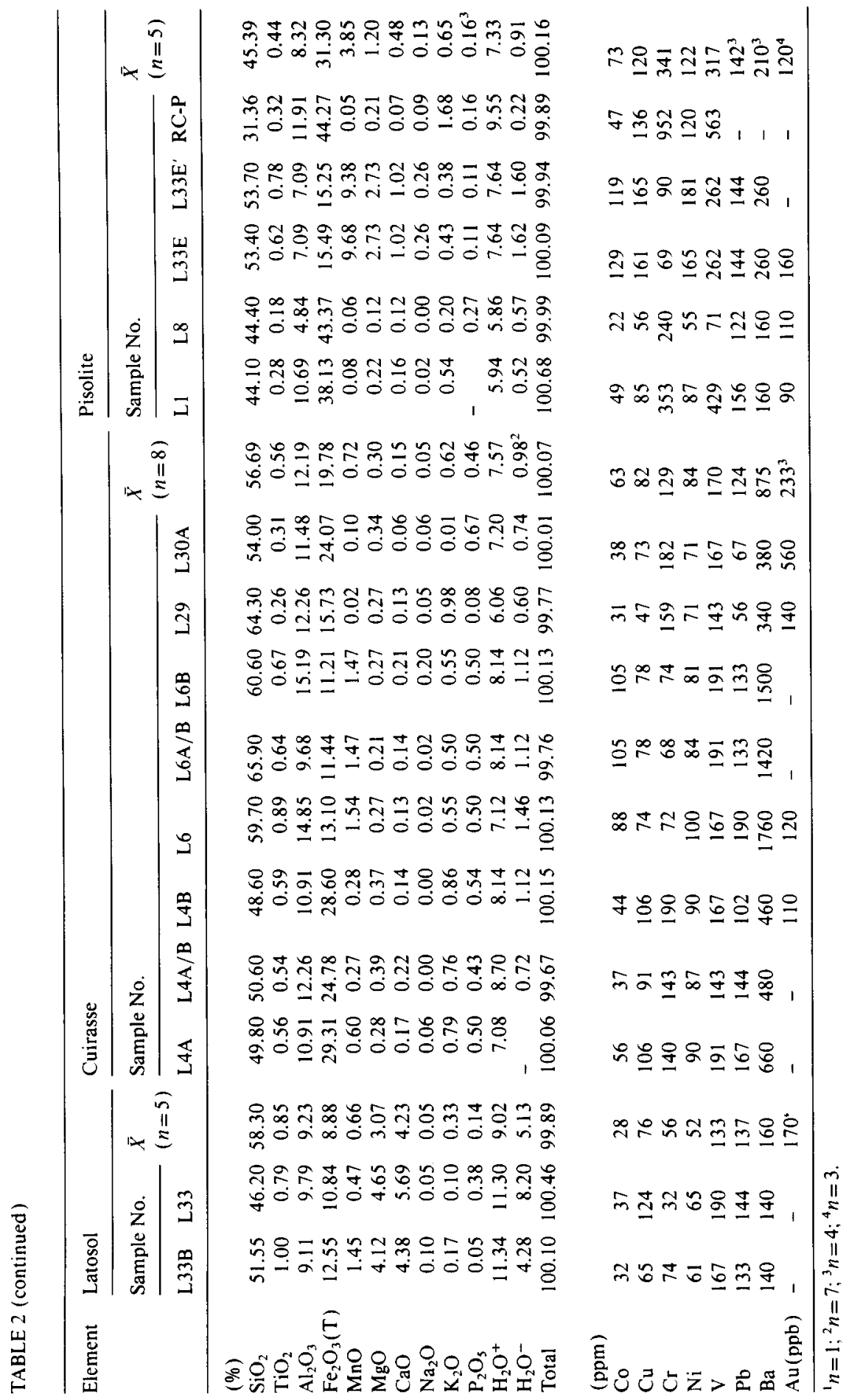


TABLE 3

Average values of REE, LREE and HREE for the parental rocks and the lateritic products from Sento Sé and Gentio do Ouro areas

\begin{tabular}{|c|c|c|c|c|c|c|c|c|c|c|}
\hline \multirow{2}{*}{$\begin{array}{l}\text { REE } \\
\bar{X}^{*} \\
(\mathrm{ppm})\end{array}$} & \multicolumn{6}{|c|}{ Sento Sé } & \multicolumn{4}{|c|}{ Gentio do Ouro } \\
\hline & $\begin{array}{l}\text { Oxide } \\
\text { facies } \\
(n=4)\end{array}$ & $\begin{array}{l}\text { Silicate } \\
\text { facies } \\
(n=1)\end{array}$ & $\begin{array}{l}\text { Iron-rich } \\
\text { carbonate } \\
(n=4)\end{array}$ & $\begin{array}{l}\text { Latosol } \\
(n=3)\end{array}$ & $\begin{array}{l}\text { Cuirasse } \\
(n=4)\end{array}$ & $\begin{array}{l}\text { Pisolite } \\
(n=3)\end{array}$ & $\begin{array}{l}\text { Gabbro } \\
(n=13)\end{array}$ & $\begin{array}{l}\text { Latosol } \\
(n=6)\end{array}$ & $\begin{array}{l}\text { Cuirasse } \\
(n=4)\end{array}$ & $\begin{array}{l}\text { Pisolite } \\
(n=2)\end{array}$ \\
\hline $\mathrm{La}$ & 28.34 & 1.92 & 3.42 & 17.20 & 10.50 & 32.77 & 17.36 & 22.75 & 14.21 & 24.12 \\
\hline $\mathrm{Ce}$ & 10.70 & 2.35 & 8.27 & 37.43 & 28.90 & 94.23 & 34.89 & 47.28 & 47.61 & 31.02 \\
\hline Nd & 13.87 & 1.99 & 6.57 & 14.00 & 9.45 & 36.48 & 24.74 & 27.49 & 15.48 & 28.87 \\
\hline $\mathrm{Sm}$ & 2.56 & 0.48 & 1.55 & 2.87 & 1.57 & 7.10 & 5.34 & 5.67 & 3.59 & 6.10 \\
\hline $\mathrm{Eu}$ & 0.53 & 0.12 & 0.30 & 0.78 & 0.50 & 1.70 & 1.75 & 1.52 & 0.94 & 1.45 \\
\hline $\bar{X} \mathrm{LREE}$ & 11.20 & 1.37 & 4.02 & 14.46 & 10.18 & 34.46 & 16.81 & 20.94 & 16.37 & 18.31 \\
\hline Gd & 1.96 & 0.53 & 1.18 & 2.53 & 1.47 & 5.69 & 6.04 & 5.16 & 3.26 & 4.63 \\
\hline Dy & 1.45 & 0.49 & 0.96 & 2.17 & 1.35 & 4.47 & 5.77 & 4.57 & 3.25 & 4.31 \\
\hline Ho & 0.27 & 0.09 & 0.19 & 0.40 & 0.31 & 0.75 & 1.14 & 0.91 & 0.63 & 0.87 \\
\hline $\mathrm{Er}$ & 0.81 & 0.27 & 0.47 & 1.29 & 0.77 & 2.20 & 3.16 & 2.60 & 1.80 & 2.48 \\
\hline $\mathrm{Yb}$ & 0.59 & 0.42 & 0.35 & 1.34 & 0.89 & 2.20 & 3.01 & 2.67 & 1.91 & 2.40 \\
\hline $\mathrm{Lu}$ & 0.09 & 0.12 & 0.08 & 0.20 & 0.14 & 0.31 & 0.42 & 0.41 & 0.29 & 0.34 \\
\hline $\bar{X}$ HREE & 0.86 & 0.32 & 0.54 & 1.32 & 0.82 & 2.60 & 3.26 & 2.72 & 1.86 & 2.50 \\
\hline $\bar{X} \mathrm{REE}$ & 5.56 & 6.80 & 2.12 & 7.29 & 5.08 & 17.06 & 9.42 & 11.00 & 8.45 & 9.69 \\
\hline
\end{tabular}

*Arithmetic mean calculated from $n$ analysed samples.

zil, and for some samples from the Gentio do Ouro District, in the laboratories of ORSTOM, France. Au was previously concentrated by fire assay. $\mathrm{SiO}_{2}$ was determined by gravimentric analysis and $\mathrm{P}_{2} \mathrm{O}_{5}$ by colorimentric analysis. The results of these analyses are given in Tables 1 (Gentio do Ouro) and 2 (Sento Sé).

The REE were determined by inductively coupled plasma (ICP) emission spectroscopy using the method described by Dutra (1984), in the Geossol Lab., Belo Horizonte, Brazil. The mean values for the samples from both studied areas are given in Table 3.

The mineralogical and petrographic data for the analysed materials have been described in Carvalho (1984, 1985) and Carvalho et al. (1987).

\section{DATA DISCUSSION AND INTERPRETATION}

Tables 1-3 show the analytical results for the bedrock and lateritic products. The mean contents of major and trace elements are in Tables $4 a$ and $b$ and the ratios of these elements to the less mobile major elements ( $\mathrm{Ti}, \mathrm{Al}$ and $\mathrm{Fe}$ ) are in Tables 5a and b. Plots for some of the elements are shown in Figures 4-8. 
TABLE 4

Average composition of major, traces and rare earth elements for the geological materials

a. Gentio do Ouro District

\begin{tabular}{|c|c|c|c|c|c|}
\hline Element & Gabbro & Latosol & Cuirasse & Pisolite & $\begin{array}{l}\text { Type of behavior } \\
\text { of the lateritic } \\
\text { product }\end{array}$ \\
\hline
\end{tabular}

\begin{tabular}{|c|c|c|c|c|c|c|c|c|}
\hline \multicolumn{9}{|l|}{$(\%)$} \\
\hline $\mathrm{SiO}_{2}$ & 48.56 & $<$ & 52.20 & $>$ & 23.90 & $<$ & 36.33 & $\mathrm{D}$ \\
\hline $\mathrm{TiO}_{2}$ & 2.84 & $>$ & 1.99 & $>$ & 1.68 & $>$ & 1.27 & A \\
\hline $\mathrm{Al}_{2} \mathrm{O}_{3}$ & 14.02 & $<$ & 15.52 & $>$ & 11.04 & $>$ & 9.91 & A \\
\hline $\mathrm{Fe}_{2} \mathrm{O}_{3}(\mathrm{~T})$ & 14.98 & $<$ & 18.83 & $<$ & 51.43 & $>$ & 36.92 & B \\
\hline $\mathrm{MnO}$ & 0.21 & $>$ & 0.17 & $>$ & 0.06 & $<$ & 0.70 & D \\
\hline $\mathrm{MgO}$ & 5.57 & $>$ & 0.22 & $>$ & 0.06 & $=$ & 0.06 & A \\
\hline $\mathrm{CaO}$ & 8.76 & $>$ & 0.19 & $>$ & 0.12 & $>$ & 0.05 & A \\
\hline $\mathrm{Na}_{2} \mathrm{O}$ & 2.23 & $>$ & 0.10 & $>$ & 0.05 & $=$ & 0.05 & A \\
\hline $\mathrm{K}_{2} \mathrm{O}$ & 0.80 & $>$ & 0.34 & $>$ & 0.11 & $>$ & 0.04 & A \\
\hline $\mathrm{P}_{2} \mathrm{O}_{5}$ & 0.25 & $>$ & 0.11 & $<$ & 0.24 & $>$ & 0.07 & B \\
\hline \multicolumn{9}{|l|}{$(\mathrm{ppm})$} \\
\hline Co & 74 & $>$ & 57 & $>$ & 17 & $>$ & 3 & A \\
\hline $\mathrm{Cu}$ & 256 & $>$ & 231 & $<$ & 236 & $>$ & 48 & B \\
\hline $\mathrm{Cr}$ & 240 & $<$ & 257 & $<$ & 259 & $<$ & 505 & $\mathrm{C}$ \\
\hline $\mathrm{Ni}$ & 60 & $>$ & 56 & $>$ & 25 & $>$ & 10 & A \\
\hline V & 528 & $>$ & 458 & $<$ & 527 & $<$ & 1000 & $\mathrm{C}$ \\
\hline $\mathrm{Pb}$ & 70 & $<$ & 128 & $>$ & 15 & $>$ & 2 & A \\
\hline $\mathrm{Ba}$ & 20 & $<$ & 66 & $>$ & 55 & $<$ & 383 & $\mathrm{D}$ \\
\hline $\bar{X}$ LREE & 16.8 & $<$ & 20.9 & $>$ & 16.4 & $<$ & 18.3 & $\mathrm{D}$ \\
\hline $\bar{X}$ HREE & 3.3 & $>$ & 2.7 & $>$ & 1.9 & $<$ & 2.5 & D \\
\hline $\bar{X} \mathrm{REE}$ & 9.4 & $<$ & 11.0 & $>$ & 8.5 & $<$ & 9.7 & D \\
\hline $\mathrm{Au}^{*}(\mathrm{~g} / \mathrm{t})$ & 2 & $<$ & 3.5 & $>$ & 2 & $>$ & - & \\
\hline
\end{tabular}

The lateritic products evolved in the order latosol-cuirasses-pisolite (Carvalho et al., 1988). The behavior of the elements within this trend is shown in Tables $4 a$ and $b$. This is a simple procedure to visualize the relative enrichment or depletion of the elements which takes into account only the compositional values. Calculations of gains and losses based upon isovolumetric alteration as suggested by several authors, e.g., Millot and Bonifas (1955), Pedro and Bittar (1966) and Tardy $(1967,1969)$, were tested by Souza (1989). He obtained different mobilities for the same element by considering its content in a given material and in the product of alteration. This is because of variations in volume changes and specific gravity reported in the same type of lateritic product from the same area. The degree of dissolution (which is higher, but not homogeneous, for banded iron-rich carbonates), the presence 
TABLE 4 (continued)

b. Sento Sé Area

\begin{tabular}{|c|c|c|c|c|c|}
\hline Element & $\begin{array}{l}\text { Iron-rich } \\
\text { carbonate }\end{array}$ & Latosol & Cuirasse & Pisolite & $\begin{array}{l}\text { Type of behavior } \\
\text { of the lateritic } \\
\text { products }\end{array}$ \\
\hline
\end{tabular}

\begin{tabular}{|c|c|c|c|c|c|c|c|c|}
\hline \multicolumn{9}{|l|}{$(\%)$} \\
\hline $\mathrm{SiO}_{2}$ & 31.75 & $<$ & 58.30 & $>$ & 56.69 & $>$ & 45.39 & A \\
\hline $\mathrm{TiO}_{2}$ & 0.33 & $<$ & 0.85 & $>$ & 0.56 & $>$ & 0.44 & A \\
\hline $\mathrm{Al}_{2} \mathrm{O}_{3}$ & 3.10 & $<$ & 9.23 & $<$ & 12.19 & $>$ & 8.32 & B \\
\hline $\mathrm{Fe}_{2} \mathrm{O}_{3}(\mathrm{~T})$ & 5.52 & $<$ & 8.88 & $<$ & 19.78 & $<$ & 31.30 & C \\
\hline $\mathrm{MnO}$ & 0.34 & $<$ & 0.66 & $<$ & 0.72 & $<$ & 3.85 & C \\
\hline $\mathrm{MgO}$ & 13.18 & $>$ & 3.07 & $>$ & 0.30 & $<$ & 1.20 & D \\
\hline $\mathrm{CaO}$ & 17.25 & $>$ & 4.23 & $>$ & 0.15 & $<$ & 0.48 & D \\
\hline $\mathrm{Na}_{2} \mathrm{O}$ & 0.05 & $=$ & 0.05 & $=$ & 0.05 & $<$ & 0.13 & C \\
\hline $\mathrm{K}_{2} \mathrm{O}$ & 0.05 & $<$ & 0.33 & $<$ & 0.62 & $<$ & 0.65 & $\mathrm{C}$ \\
\hline $\mathrm{P}_{2} \mathrm{O}_{5}$ & 0.18 & $>$ & 0.14 & $<$ & 0.46 & $>$ & 0.16 & B \\
\hline \multicolumn{9}{|l|}{$(\mathrm{ppm})$} \\
\hline $\mathrm{Co}$ & 25 & $<$ & 28 & $<$ & 63 & $<$ & 73 & $\mathrm{C}$ \\
\hline $\mathrm{Cu}$ & 28 & $<$ & 76 & $<$ & 82 & $<$ & 120 & $\mathrm{C}$ \\
\hline $\mathrm{Cr}$ & 15 & $<$ & 56 & $<$ & 129 & $<$ & 341 & $\mathrm{C}$ \\
\hline $\mathrm{Ni}$ & 38 & $<$ & 52 & $<$ & 84 & $<$ & 122 & $\mathrm{C}$ \\
\hline V & 83 & $<$ & 133 & $<$ & 170 & $<$ & 317 & $\mathrm{C}$ \\
\hline $\mathrm{Pb}$ & 113 & $<$ & 137 & $>$ & 124 & $<$ & 142 & D \\
\hline $\mathrm{Ba}$ & 100 & $<$ & 160 & $<$ & 875 & $>$ & 210 & B \\
\hline $\bar{X} \mathrm{LREE}$ & 4.0 & $<$ & 14.5 & $>$ & 10.2 & $<$ & 34.5 & $\mathrm{D}$ \\
\hline $\bar{X}$ HREE & 0.5 & $<$ & 1.3 & $>$ & 0.8 & $<$ & 2.6 & $\mathrm{D}$ \\
\hline $\bar{X} \mathrm{REE}$ & 2.1 & $<$ & 7.3 & $>$ & 5.1 & $<$ & 17.1 & $\mathrm{D}$ \\
\hline $\mathrm{Au}(\mathrm{ppb})$ & 50 & $<$ & 170 & $<$ & 230 & $>$ & 120 & B \\
\hline
\end{tabular}

*Values obtained from ore treatment (Garimpo do Gaucho).

of "skelet" or preserved primary mineral [e.g., quartz in the products of alteration from gabbros at the contact zone (Gentio do Ouro District), magnetite in the latosols on gabbros (Gentio do Ouro District) and on banded iron-rich carbonates (Sento Sé Area), and fragments of "itabirite" (banded oxide facies iron formation in the brecciated (conglomeratic) type of cuirasse from the Sento Sé Area) ], the texture (including here the organization for the plasm in the cuirasses and pisolites), hydration and dehydration (formation and evolution of clay minerals and oxihydroxides ) affected both volume and specific gravity. Souza (1989) suggested the examination of the contents of each analysed element as tabulated in Table 4 and their ratios to $\mathrm{Ti}$, $\mathrm{Al}$ and $\mathrm{Fe}$ as presented in Table 5 to indicate the relative concentration. 
TABLE 5

Ratios of major and trace elements to $\mathrm{TiO}_{2}(1), \mathrm{Al}_{2} \mathrm{O}_{3}(2)$ and $\mathrm{Fe}_{2} \mathrm{O}_{3}(\mathrm{~T})(3)$ for the geological materials a. Gentio do Ouro District

\begin{tabular}{|c|c|c|c|c|c|c|c|c|c|c|c|c|}
\hline \multirow[t]{2}{*}{ Element } & \multicolumn{3}{|l|}{ Gabbro } & \multicolumn{3}{|l|}{ Latosol } & \multicolumn{3}{|c|}{ Cuirasse } & \multicolumn{3}{|l|}{ Pisolite } \\
\hline & 1 & 2 & 3 & 1 & 2 & 3 & 1 & 2 & 3 & 1 & 2 & 3 \\
\hline $\mathrm{SiO}_{2}$ & 17.10 & 3.46 & 3.24 & 26.23 & 3.36 & 2.77 & 14.23 & 16 & .46 & 28.61 & 3.67 & 0.98 \\
\hline $\mathrm{TiO}_{2}$ & 1.00 & 0.20 & 0.19 & 1.00 & 0.13 & 0.11 & 1.00 & 15 & 0.03 & 1.00 & 0.13 & 0.03 \\
\hline $\mathrm{Al}_{2} \mathrm{O}_{3}$ & 4.94 & 1.00 & 0.94 & 7.80 & 1.00 & 0.82 & 6.57 & 1.00 & 0.21 & 7.80 & .00 & 0.27 \\
\hline $\mathrm{Fe}_{2} \mathrm{O}_{3}(\mathrm{~T})$ & 5.28 & 1.07 & 1.00 & 9.46 & 1.21 & 1.00 & 30.61 & 4.66 & .00 & 29.07 & .73 & 1.00 \\
\hline $\mathrm{MnO}$ & 0.07 & 0.01 & 0.01 & 0.09 & 0.01 & 0.01 & 0.04 & 0.01 & 0.00 & 0.55 & 0.07 & 0.02 \\
\hline $\mathrm{MgC}$ & 6 & 0.40 & 0.37 & 0.11 & 0.01 & 0.01 & 0.04 & 0.01 & 0.00 & 0 & .01 & 0.00 \\
\hline $\mathrm{Ca}$ & 3 & 0.62 & 0.58 & 0.10 & 0.01 & 0.01 & 0.0 & 0.01 & 0.00 & 0.04 & .01 & 0.00 \\
\hline $\mathrm{Na}_{2} \mathrm{O}$ & 9 & 0.16 & 0.15 & 0.05 & 0.01 & 0.01 & 0.03 & 0.01 & 0.00 & 0.04 & 0.01 & 0.00 \\
\hline $\mathrm{K}_{2} \mathrm{O}$ & 8 & 0.06 & 0.05 & 0.17 & 0.02 & 0.02 & 0.07 & 0.01 & 0.00 & 0.03 & 0.00 & 0.00 \\
\hline $\mathrm{P}_{2} \mathrm{O}_{5}$ & 0.09 & 0.02 & 0.02 & 0.06 & 0.01 & 0.01 & 0.01 & 0.02 & 0.00 & 0.06 & 0.01 & 0.00 \\
\hline \multicolumn{13}{|l|}{$\left(\times 10^{4}\right)$} \\
\hline Co & .06 & 5.28 & 4.94 & 3.64 & 3.67 & 3.03 & 2 & 54 & 33 & 2.36 & 0.30 & 0.08 \\
\hline $\mathrm{Cu}$ & 90.14 & 18.33 & 18.26 & 116.08 & 14.88 & 12.27 & 140.48 & 21.38 & 4.59 & 37.80 & 4.84 & 1.30 \\
\hline $\mathrm{Cr}$ & 84.50 & 17.12 & 16.02 & 129.15 & 16.56 & 13.65 & 154.17 & 23.46 & 5.03 & 397.64 & 50.96 & 13.68 \\
\hline $\mathrm{Ni}$ & 21.13 & 4.28 & 4.01 & 28.14 & 3.61 & 2.97 & 14.88 & 2.26 & 0.49 & 7.87 & 1.01 & 0.27 \\
\hline V & 185.92 & 37.66 & 35.25 & 230.15 & 29.51 & 24.32 & 313.69 & 47.74 & 10.25 & 787.40 & 101.91 & 27.09 \\
\hline 0 & 4.67 & 4.99 & 4.67 & 64.32 & 8.25 & 6.80 & 8.93 & 1.36 & 0.29 & 1.57 & 0.20 & 0.05 \\
\hline$\nabla$ & & 1.43 & 1.34 & 37.17 & 4.25 & 3.51 & 32.74 & 4.98 & 1.07 & 301.57 & 38.65 & 10.37 \\
\hline & & 1.20 & 1.12 & 10.50 & 1.35 & 1.1 & 9.76 & 1.48 & 0.32 & 14.41 & 1.85 & 0.50 \\
\hline & & 0.23 & 0.22 & 1.36 & 0.18 & 0.1 & 1.1 & 0.17 & 0.04 & 1.97 & 0.25 & 0.07 \\
\hline $\bar{X} \mathrm{RE}$ & & 0.67 & 0.63 & 5.53 & 0.71 & 0.58 & 5.06 & 0.77 & 0.16 & 7.64 & 0.98 & 0.26 \\
\hline $\mathrm{Au}\left(\times 10^{7}\right)$ & 0.70 & 0.14 & 0.13 & 1.76 & 0.23 & 0.19 & 1.19 & 0.18 & 0.04 & - & - & _- \\
\hline
\end{tabular}

\section{MAJOR ELEMENTS}

The distribution of $\mathrm{SiO}_{2}, \mathrm{Al}_{2} \mathrm{O}_{3}$ and $\mathrm{Fe}_{2} \mathrm{O}_{3}$ as total iron (Fig. 4) shows that: (a) there exists a tendency for iron enrichment of the lateritic products;

(b) the field of distribution of the plotted values for the latosols may totally (Gentio do Ouro) or partially (Sento Sé) overlap values for the parent rocks;

(c) relative to $\mathrm{SiO}_{2}$ and $\mathrm{Fe}_{2} \mathrm{O}_{3}(\mathrm{~T})$, the field of distribution of the pisolites exhibits the largest dispersion. This situation is more conspicuous for the Gentio do Ouro District (Fig. 4a) where the pisolites contain less Fe than the cuirasses.

The distribution of the studied materials in the ternary diagram of mobile elements $\left(\mathrm{Na}_{2} \mathrm{O}+\mathrm{K}_{2} \mathrm{O}+\mathrm{MgO}+\mathrm{CaO}\right)$ vs. $\left(\mathrm{MnO}+\mathrm{P}_{2} \mathrm{O}_{5}\right)$ vs. immobile elements $\left(\mathrm{TiO}_{2}+\mathrm{Fe}_{2} \mathrm{O}_{3} \mathrm{~T}+\mathrm{Al}_{2} \mathrm{O}_{3}\right)$ (Fig. 5) shows that;

(d) some lateritic products show an inheritance from the original rock type in terms of their composition. The influence of the parent rock type is indicated by the higher content of alkaline earth metals in the latosols derived 
TABLE 5 (continued)

b. Sento Sé Area

\begin{tabular}{|c|c|c|c|c|c|c|c|c|c|c|c|c|}
\hline \multirow[t]{2}{*}{ Element } & \multicolumn{3}{|c|}{ Iron-rich carbonate } & \multicolumn{3}{|l|}{ Latosol } & \multicolumn{3}{|l|}{ Cuirasse } & \multicolumn{3}{|c|}{ Pisolite } \\
\hline & 1 & 2 & 3 & 1 & 2 & 3 & 1 & 2 & 3 & 1 & 2 & 3 \\
\hline $\mathrm{O}_{2}$ & 96.21 & 10.24 & 5.75 & 8.59 & 6.31 & 6.57 & 01,23 & 4.65 & .87 & 103.16 & 5.46 & 1.40 \\
\hline $\mathrm{iO}_{2}$ & 1.00 & 0.11 & 0.06 & 1.00 & 0.09 & 0.09 & 1.00 & 0.05 & .03 & 1.00 & 0.05 & 0.01 \\
\hline $\mathrm{l}_{2} \mathrm{O}_{3}$ & 9.39 & 1.00 & 0.56 & 10.86 & 1.00 & 1.04 & 21.77 & 1.00 & 0.62 & 18.91 & 1.00 & 0.27 \\
\hline $\mathrm{Fe}_{2} \mathrm{O}_{3}(\mathrm{~T})$ & 16.73 & 1.78 & 1.00 & 10.45 & 0.96 & 1.00 & 35.32 & 1.62 & 1.00 & 71.14 & 3.76 & 1.00 \\
\hline $\mathrm{MnO}$ & 1.03 & 0.11 & 0.06 & 0.78 & 0.07 & 0.07 & 1.29 & 0.06 & 0.04 & 8.75 & 0.46 & 0.12 \\
\hline 40 & 39 & 4.25 & 2.39 & 1 & 0.33 & 0.35 & 0.53 & 0.02 & 02 & 73 & & 0.04 \\
\hline $\mathrm{CaC}$ & 7 & 5.56 & 3.13 & & 0.46 & 0.48 & 0.27 & 0.01 & .00 & 1.09 & 0.06 & 0.02 \\
\hline $\mathrm{Na}_{2} \mathrm{O}$ & & 0.02 & 0.01 & 0.06 & 0.00 & 0.00 & 0.09 & 0.00 & 0.00 & 0.29 & 0.02 & 0.00 \\
\hline $\mathbf{K}_{2} \mathrm{O}$ & 5 & 0.02 & 0.01 & 0.39 & 0.04 & 0.04 & 1.11 & 0.05 & 0.03 & 1.48 & 0.08 & 0.02 \\
\hline $\mathbf{P}_{2} \mathrm{O}_{5}$ & 5 & 0.06 & 0.03 & 0.16 & 0.02 & 0.02 & 0.82 & 0.04 & 0.02 & 0.36 & 0.02 & 0.00 \\
\hline \multicolumn{13}{|l|}{$(\times 10$} \\
\hline Co & 6 & 06 & 4 & 94 & 3 & & & 17 & 19 & & .77 & 2.33 \\
\hline & & 13 & 5 & & 3 & 6 & & 73 & 15 & & & 33 \\
\hline$r$ & & & 2. & & & & 36 & 10 & 52 & & 40 & 10.89 \\
\hline & 11 & 12.26 & 6.88 & 8 & 5.63 & & 00 & 6.89 & 4.25 & 277.27 & 14.66 & 3.90 \\
\hline 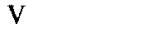 & 1.52 & 26.77 & 15.04 & 156 & 14.41 & 14. & 30 & 13.95 & 8.59 & 72 & 38.10 & 10.13 \\
\hline $\mathrm{Pl}$ & 2.42 & 36.45 & 20.47 & 161.18 & 14.84 & 15 & 221.43 & 10.17 & 6.27 & 322.73 & 17.07 & 4.54 \\
\hline $\mathbf{E}$ & 303.03 & 32.26 & 18.12 & 188.24 & 17.34 & 18.02 & 1562.50 & 71.78 & 44.24 & 477.27 & 25.24 & 6.71 \\
\hline & 12.12 & 1.29 & 0. & 17.06 & 1.57 & 1.63 & 18.21 & 0.84 & 0.52 & 78.41 & 4.15 & 1.10 \\
\hline $\bar{X} \mathbf{H}$ & 1.52 & 0.16 & 0.09 & & 0.14 & 0.15 & 1.43 & 0.07 & 0.04 & 5.91 & 0.31 & 0.08 \\
\hline $\bar{X} \mathbf{R I}$ & 6.36 & 0.67 & 0.38 & 8.59 & 0.79 & 0.82 & 9.11 & 0.42 & 0.26 & 38.86 & 2.06 & 0.55 \\
\hline $\mathrm{Au}\left(\times 10^{7}\right)$ & 151.52 & 16.13 & 9.06 & 200.00 & 18.42 & 19.14 & 410.71 & 18.87 & 11.63 & 272.73 & 14.42 & 3.83 \\
\hline
\end{tabular}

from the iron-rich carbonates (Sento Sé) than in those originating from gabbros (Gentio do Ouro);

(e) for the lateritic products from Gentio do Ouro, the polarization towards $\left(\mathrm{TiO}_{2}+\mathrm{Fe}_{2} \mathrm{O}_{3} \mathrm{~T}+\mathrm{Al}_{2} \mathrm{O}_{3}\right)$ is more noticeable than that observed for the equivalent products from Sento Sé.

Actually, for the Sento Sé area, the field of distribution for the cuirasses and especially that for the pisolites shows a tendency to be elongated towards the $\left(\mathrm{MnO}+\mathrm{P}_{2} \mathrm{O}_{5}\right)$ edge of the diagram. This is due to the increasing content of $\mathrm{MnO}$ in the sense latosol $<$ cuirasse $<$ pisolite and the relatively minor mobility of $\mathrm{MnO}$ and $\mathrm{P}_{2} \mathrm{O}_{5}$ in the laterite from Sento Sé (Tables 4 and 5 ).

As can be seen in the correlation diagram between $\mathrm{Al}_{2} \mathrm{O}_{3}$ and $\mathrm{Fe}_{2} \mathrm{O}_{3}$ (Fig. 6):

(f) for gabbros, there is an inverse relationship between these oxides as lateritization proceeds (Fig. 6a), and a coincident increase for these elements in the latosols and cuirasses developed on the iron-rich carbonates (Fig. 6b). The values in Table 5 corroborate these observations and show that there is a 


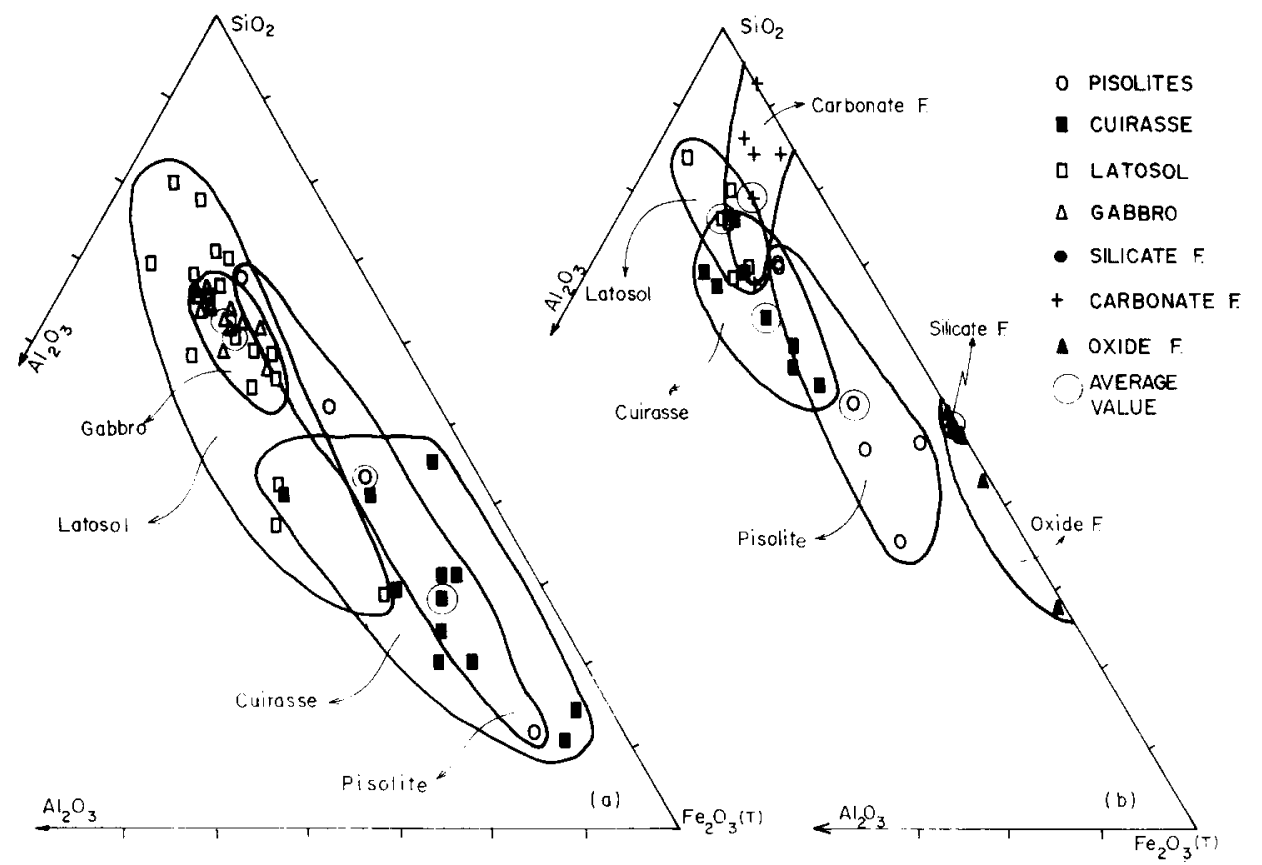

Fig. 4. Triangular diagram for $\mathrm{Al}_{2} \mathrm{O}_{3}-\mathrm{SiO}_{2} \mathrm{O}-\mathrm{Fe}_{2} \mathrm{O}_{3}(\mathrm{~T})$ showing the fields of distribution for (a) gabbros and lateritic products from Gentio do Ouro and (b) the facies of iron formation and the lateritic products of Sento Sé.
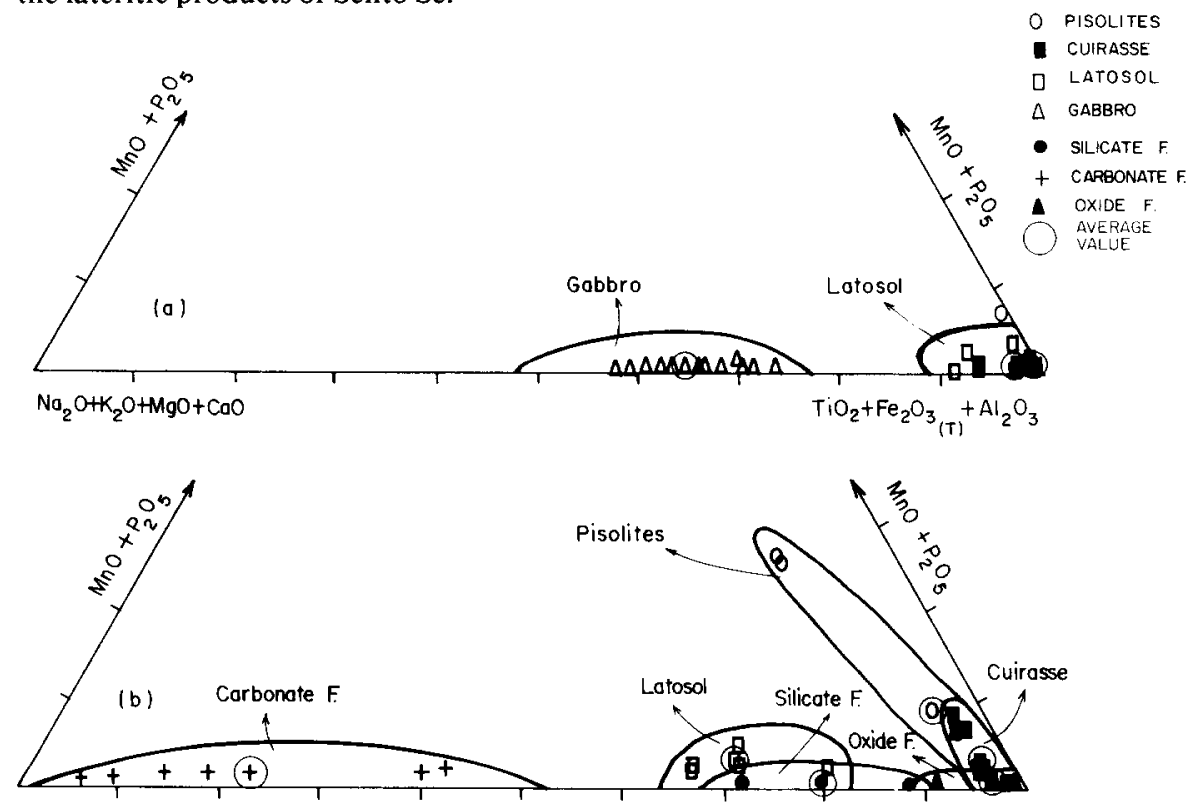

$\mathrm{Na}_{2} \mathrm{O}+\mathrm{K}_{2} \mathrm{O}+\mathrm{MgO}+\mathrm{CaO}$

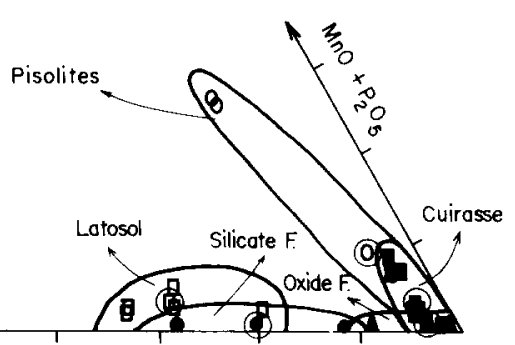

$$
\mathrm{TiO}_{2}+\mathrm{Fe}_{2} \mathrm{O}_{3}(\mathrm{~T})+\mathrm{Al}_{2} \mathrm{O}_{3}
$$

Fig. 5. Triangular diagram for $\mathrm{Na}_{2} \mathrm{O}+\mathrm{K}_{2} \mathrm{O}+\mathrm{MgO}+\mathrm{CaO}-\mathrm{MnO}+\mathrm{P}_{2} \mathrm{O}_{5}-\mathrm{TiO}_{2}+\mathrm{Fe}_{2} \mathrm{O}_{3}(\mathrm{~T})$ $+\mathrm{Al}_{2} \mathrm{O}_{3}$, showing the field of distribution for (a) gabbros and lateritic products from Gentio do Ouro and (b) the facies of iron formation and the lateritic products of Sento Sé. 


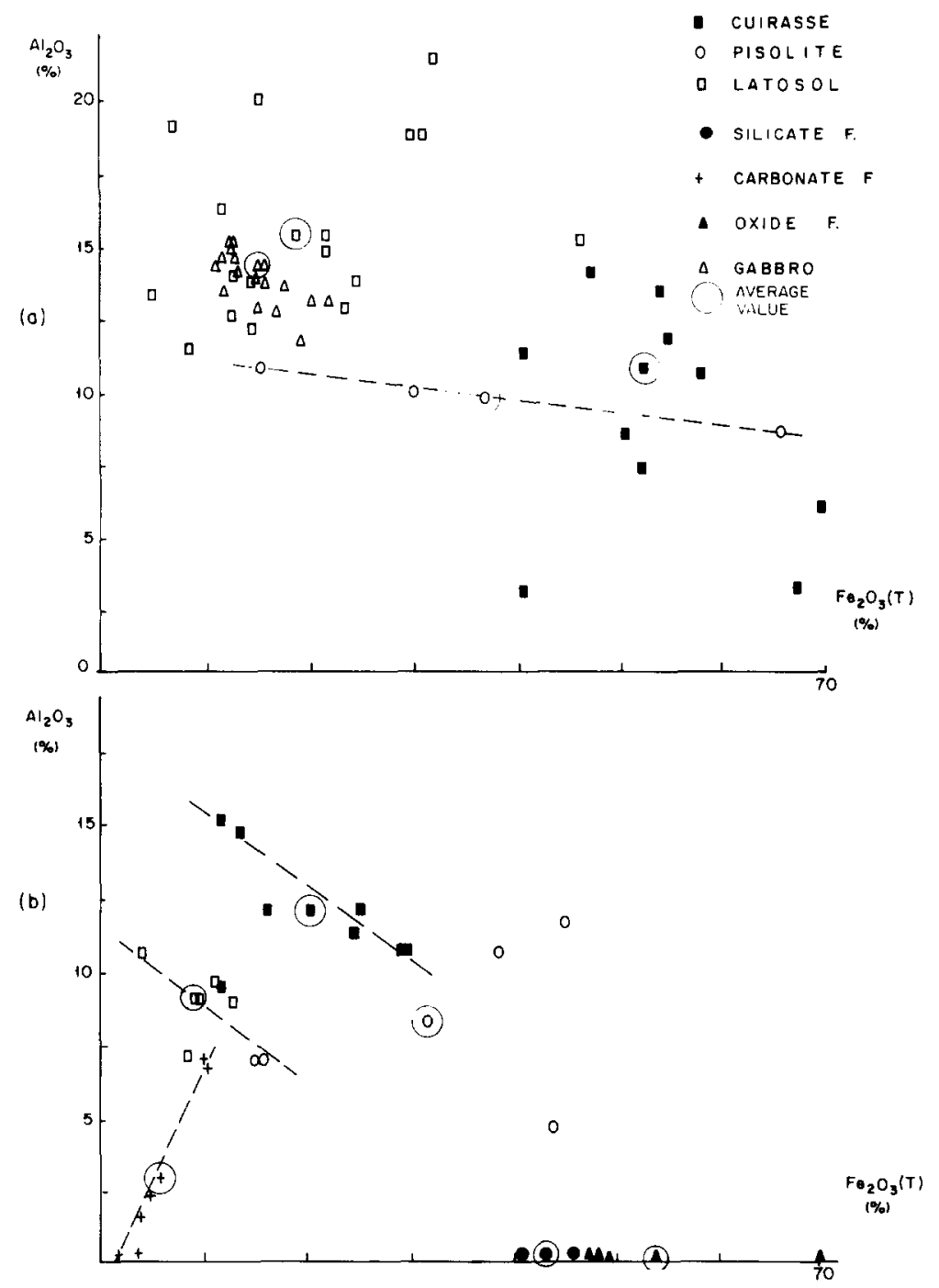

Fig. 6. Distribution of $\mathrm{Al}_{2} \mathrm{O}_{3}$ vs. $\mathrm{Fe}_{2} \mathrm{O}_{3}(\mathrm{~T})$ values for parental rocks and lateritic products from (a) Gentio do Ouro and (b) Sento Sé.

depletion in $\mathrm{Al}$ relative to $\mathrm{Fe}$ as weathering proceeds on gabbros and that $\mathrm{Al}$ is more concentrated than $\mathrm{Fe}$ in the latosols and cuirasses on the iron-rich carbonates;

(g) $\mathrm{Al}_{2} \mathrm{O}_{3}$ correlates strongly with $\mathrm{Fe}_{2} \mathrm{O}_{3}$ for the iron-rich carbonates (Fig. $6 \mathrm{~b})$, but no significant $\mathrm{Al}_{2} \mathrm{O}_{3}$ is reported in the oxide $(<0.6 \%)$ and silicate $(<0.5 \%)$ facies iron formation (Table 2$)$.

The presence of well-preserved blocks of itabirite (quartzitic bands alternated with hematitic bands) in the brecciated or conglomeratic type of cuir- 
asse suggests that there was no other material contribution from the oxide facies iron formation to the lateritic cover of the Sento Sé Area. Fragments of banded amphibole-magnetite-rich rocks (silicate facies of BIF) are not reported in this cover, however, magnetite may be disseminated in the latosol in content as much as $5 \%$ in weight. These observations suggest that the silicate facies iron formation may provide part of the iron (from oxidation and hydration of magnetite and hydrolysis or iron-rich silicates) to the lateritic mantle.

\section{TRACE ELEMENTS}

Although some trace elements exhibit higher contents in the lateritic materials on parent rock in which their contents are high (inheritance factor;
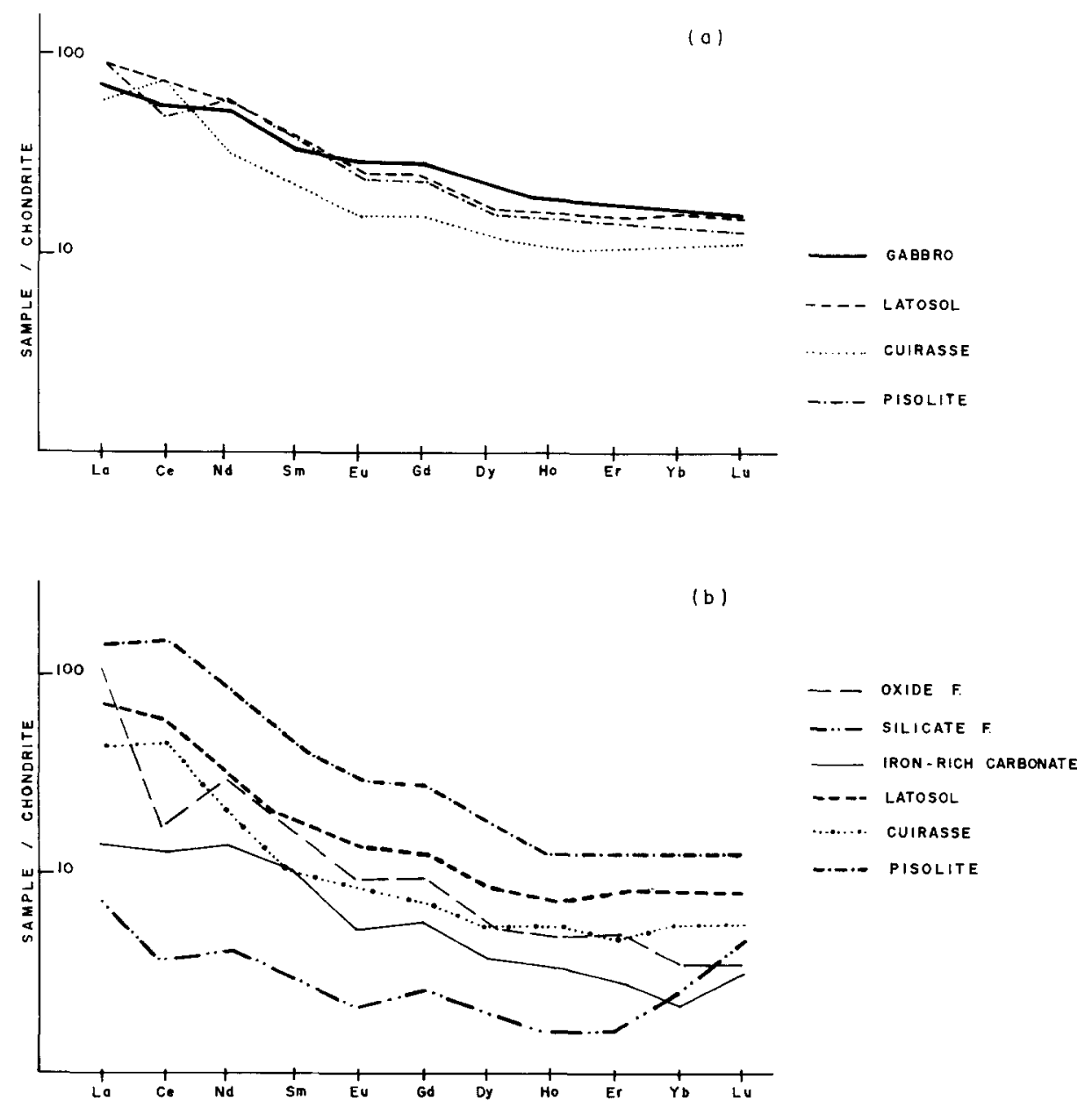

Fig. 7. Distribution of average values of REE normalized to chondrites, in the geological materials from (a) Gentio do Ouro and (b) Sento Sé. 

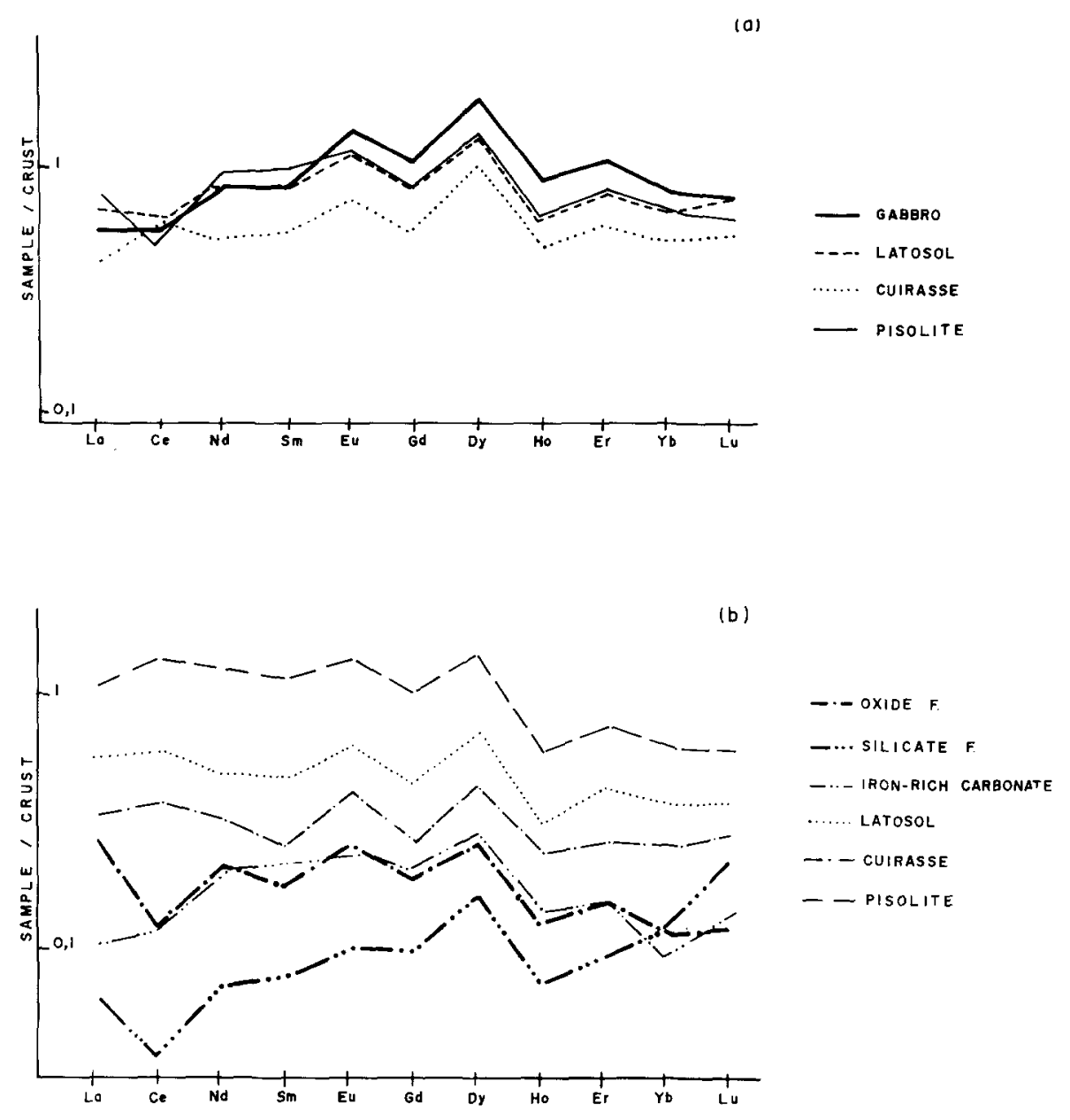

Fig. 8. Distribution of REE normalized to crustal values in the geological materials from (a) Gentio do Ouro and (b) Sento Sé.

e.g., $\mathrm{Cr}$ and $\mathrm{V}$ on gabbros and $\mathrm{Pb}$ on iron-rich carbonates), the contents of trace elements (Table 1-4) suggest that their mobilities were not the same in the studied lateritic covers. It must be pointed out that only $\mathrm{Cr}, \mathrm{V}$ and REE have the same type of mobility (type C, C and D, respectively) in both areas.

For the Sento Sé Area $\mathrm{Co}, \mathrm{Cu}, \mathrm{Ni}, \mathrm{Cr}$ and $\mathrm{V}$ have behavior type $\mathrm{C}$, that is their contents clearly tend to increase towards the final product of weathering (pisolite). Ba and $\mathrm{Au}$ have behavior type $\mathrm{B}$. REE and to a certain extent $\mathrm{Pb}$ (cf. Table 5b) have behavior type D.

For the Gentio do Ouro District $\mathrm{Co}, \mathrm{Cu}, \mathrm{Ni}$ and $\mathrm{Pb}$ tend to increase (for $\mathrm{Cu}$, see ratio $\mathrm{Cu} / \mathrm{Fe}_{2} \mathrm{O}_{3}(\mathrm{~T})$ in Table 5a) towards the latosol.

The patterns of distribution of REE values normalized to crustal values show 
a positive anomaly of Eu and Dy for all types of lateritic products as well as for the iron-rich carbonates, silicate facies iron formation and gabbros (Fig. 8 ). The REE patterns in the lateritic products from Gentio do Ouro show a depletion in HREE plus $\mathrm{Ce}$ and an enrichment in LREE (except for $\mathrm{Ce}$ ) in the latosols and pisolites relative to the parental gabbros. This behavior is present for both normalization procedures (Figs. $7 \mathrm{a}$ and $8 \mathrm{a}$ ).

In the Sento Se area the oxide and silicate facies of iron formation and the iron-rich carbonates exhibit negative anomalies of Ce though the anomaly in the carbonates is very weak. In contrast, all the lateritic products are richer in REE than the silicate facies iron formation and the parental iron-rich carbonates (Figs. $7 \mathrm{~b}$ and $8 \mathrm{~b}$ ).

The main distinguishing feature between the REE distribution patterns of Gentio do Ouro District and those of Sento Sé are:

(a) The parent rock (gabbros) and their weathering products (iron-rich laterites) in the Gentio do Ouro District exhibit narrow variations in the REE contents. In contrast, the REE contents in the silicate facies iron formation, iron-rich carbonates and in the derived lateritic materials show a wide range of variation.

(b) In terms of the parent rocks, the lateritic products derived from ironrich carbonates at Sento Sé are enriched in REE. From the gabbros at Gentio do Ouro the lateritic products tend to be depleted, at least for the HREE plus $\mathrm{Eu}$ in the case of latosol and pisolite, and for all REE (including $\mathrm{Ce}$ ) for the cuirasses. However, even though showing an enrichment, the iron-rich lateritic materials which are derived from iron-rich carbonates (Sento Sé Area) tend to be poorer in REE than their counterparts derived from gabbros (Gentio do Ouro Area ), the only exception being the pisolites from Sento Sé which have higher values of LREE than the others weathering products.

(c) The overall geochemical behavior for the REE in the iron-rich lateritic products of the investigated areas is defined as type $\mathrm{D}$, that is analogous to the behavior of $\mathrm{Si}, \mathrm{Mn}$ and $\mathrm{Ba}$ in the Gentio do Ouro District and to $\mathrm{Mg}, \mathrm{Ca}$ and $\mathrm{Pb}$ in the Sento Sé Area.

\section{CONCLUSIONS}

The data suggest some general features of environment and element behavior during lateritization in the Gentio do Ouro and Sento Sé areas.

The differences in composition of the parent rocks seem not to be directly reflected in the distribution of some elements (e.g., $\mathrm{Si}, \mathrm{Na}, \mathrm{K}, \mathrm{P}, \mathrm{Co}$ and $\mathrm{Ni}$ ) in the lateritic products although the contents of some elements in these products may reflect, quantitatively, an inheritance from the original rocks (e.g., $\mathrm{Ti}, \mathrm{Fe}, \mathrm{Mn}, \mathrm{Mg}, \mathrm{Ca}, \mathrm{Cr}, \mathrm{V}$ and $\mathrm{Pb}$ ). $\mathrm{Al}, \mathrm{REE}$ and $\mathrm{Cu}$ may be included in the latter category (inherited elements) but the content of $\mathrm{Al}$ in the cuirasses and the contents of REE and $\mathrm{Cu}$ in the pisolites derived from the iron-rich carbon- 
ates at Sento Sé are higher than their counterparts derived from gabbros at Gentio do Ouro.

The evolutionary trend is: original rock-latosol-cuirasse-pisolite. In terms of major element contents the latter lateritic product exhibits a widespread variation especially when the original rock is the gabbro. Following this trend, the expected geochemical coherence among some elements is not always observed.

This is the case for $\mathrm{Co}, \mathrm{Cu}$ and $\mathrm{Ni}$ in the lateritic cover at Gentio do Ouro, alkaline and alkaline earth metals in the lateritic cover of Sento Sé, and Fe, $\mathrm{Ti}, \mathrm{Al}, \mathrm{Mn}, \mathrm{Pb}, \mathrm{Ba}$ and $\mathrm{Au}$ in the lateritic materials from both areas.

The ratios to the immobile elements indicate a concentration of Fe relative to $\mathrm{Ti}$ and $\mathrm{Al}$ in the latosols on gabbros and inversely a concentration of $\mathrm{Ti}$ and $\mathrm{Al}$ relative to $\mathrm{Fe}$ in the latosols on iron-rich carbonates.

In both examples of rock alteration into latosol, an intense leaching of alkaline earth metals took place and it was more effective in the latosol on gabbros where $\mathrm{Na}$ and $\mathrm{K}$ were equally affected.

The gain in $\mathrm{K}$ in the latosol on the iron-rich carbonates results from neoformation of illite. The contents of $\mathrm{K}$ and $\mathrm{Na}$ (alkaline elements) in the latosols of both studied areas are assumed to be normal (Souza, 1989).

Primary talc and $\mathrm{Mg}$ chlorite plus secondary chlorites and smectite explain the higher content of $\mathrm{Mg}$ in the lateritic products on iron-rich carbonates. Secondary carbonates, resulting from carbonate-rich solution, contribute to the higher content of $\mathrm{Ca}$ and also of $\mathrm{Mg}$ in the lateritic cover on iron-rich carbonates (Souza, 1989). Talc and carbonates are not observed and chlorite and smectite are trace minerals rarely reported in the red latosols on gabbros.

The REE in both Gentio do Ouro and Sento Sé areas consistently show type $D$ behavior (lowest values in the cuirasses) and their distributions exhibit a similar pattern which is most noticeable for the HREE. When the REE values are normalized to chondrites, a negative $\mathrm{Ce}$ anomaly is only observed in the pisolites at Gentio do Ouro (gabbro-derived lateritic cover). This Ce anomaly in pisolites is enhanced and a slight negative anomaly appears in the latosols on gabbros when the REE values are normalized to the crustal values of Mason (1985) (Fig. 8a).

The Ce enrichment in the lateritic products is interpreted as due to the oxidation of $\mathrm{Ce}^{2+}$ and adsorption of $\mathrm{Ce}^{4+}$ by amorphous oxyhydroxides of iron and aluminum, followed by washing down (eluviation of these oxyhydroxides) to accumulate as limonite in the $B$ horizon of the soil that evolves downwards. Such a highly oxidizing condition should occur above the water level. If this is so, than below the interface of the $\mathrm{B}$ and $\mathrm{C}$ horizons, the conditions were not oxidizing enough to oxidize both $\mathrm{Eu}^{2+}$ and $\mathrm{Ce}^{2+}$. Because of the geochemical coherence resulting from the similarity in size of $\mathrm{Eu}^{2+}$ and $\mathrm{Ca}^{2+}$ it is expected that at least a portion of Eu may be leached, following the $\mathrm{Ca}$ ion, from the place of rock alteration (saprolite or C horizon ). Nesbitt (1979) 
pointed out that this mobility of Eu occurs in acidic solutions. The derived latosol, having a lower content in this element than the parental gabbro, suggests a partial mobility of $\mathrm{Eu}^{2+}$ under low $\mathrm{pH}$ environmental conditions.

These observations are evidences that the main control of the REE mobility acts at the beginning of the alteration of the original rock at depth. In such a situation, the solution resulting from the hydrolysis-dissolution processes has a basic character, because of $\mathrm{OH}$ generation. Dissolution is important in soil formation from carbonates. An acid weathering solution is necessary to leach $\mathrm{Eu}$ (Moller et al., 1981) and other trace elements (e.g., Co, Ni, Cu). It is also necessary to remove primary gold (Mann, 1984; Carvalho, 1985) from the reduced native form and to put it into solution as an $\mathrm{Au}^{3+}$ complex. This gold-bearing solution can change its acidic character by mixing with deeper basic solutions or by changes in $\mathrm{pH}$ due to the process of rock alteration from hydrolysis of silicates. If enough sulfides are present in the parent rock to generate acidic solutions, and if primary gold is available in this rock to be scavenged, gold will be dissolved and reprecipitated in the weathering cover to form lateritic gold mineralization. This phenomenon seems to have occurred at the Gentio do Ouro District.

\section{ACKNOWLEDGEMENTS}

This study is part of the project "Gold in Ferralites of the Semi-Arid Region of the State of Bahia, Brazil" which received financial support during 1966-1968 from PADCT (Contract No. 42.86.0345.00). The authors thank Dr.F. Soubies (ORSTOM) for help in providing some chemical analyses, Dr. Jonathan Evans of BP Research Centre (England) for proofreading and helpful suggestions and graduate student Idelvone M. Ferreira for drafting services.

\section{REFERENCES}

Carvalho, I.G., 1984. Mineralizaçòes auriferas de Gentio do Ouro Bahia. Caracteristicas micromorfologicas. XXXIII Congr. Brasil Geol., 3: 4024-4040.

Carvalho, I.G., 1985. Contribuicao ao conhecimento genetico das mineralizacoes auriferas tipo Gentio do Ouro. Estado da Bahia. UFBA, Unpubl. thesis, 92 pp.

Carvalho, I.G., 1986. Caracterizacao quimica das Couracas e materials lateriticos associados as ocorrencias tipo Gentio do Ouro. XXXIV Congr. Brasil Geol., 6: 2830-2841.

Carvalho, I.G., Mestrinho, S.S.P. and Goel, O.P., 1987. Alguns Aspectos de coberturas lateriticas de regiao semi-arida do Estado da Bahia. Laterita aurifera da Porcao ocidental da Chapada Diamantina e laterita do Municipio de Sento Sé. 1 Congr. Brasil. Geol., 2: 53-68.

Carvalho, I.G., Mestrinho, S.S.P. and Goel, O.P., 1988. Comportamento geoquimico de elementos tracos nas lateritas ferruginosas de Sento Sé, Estado da Bahia. XXXV Congr. Brasil. Geol., 4: 1878-1899.

Dutra, C.V., 1984. Metodo para Determinacao de Tracos e Sub-Iracos de Terra Raras em Ro- 
chas por Espectrometria de Plasma ICP. Apliacacao em Petrogenese. XXXIII Congr. Brasil. Geol., 10: 4792-4805.

Evensen, N.M., Hamilton, P.J. and O'Nions, R.K., 1978. Rare earth abundance in chondritic meteorites. Geochim. Chosmochim. Acta., 42: 1199-1212.

Mann, A.W., 1984. Mobility of gold and silver in lateritic weathering profiles: Some observations from Western Australia. Econ. Geol., 79: 38-49.

Mason, B.H., 1985. Principles of Geochemistry. 4th Wiley Eastern Limited, New Deli, ed, 350 pp.

Millot, G. and Bonifas, M., 1955. Transformations isovolumetriques dans les phenomenes de lateritisation et de bauxitisation. Bull. Serv. Carte Geol. Alsace Lorraine, 8: 3-20.

Moller, P., Dulski, F., Schley, J.L., Luch, J. and Szacki, W., 1981. A new way of interpreting trace element concentrations with respect to models of mineral formation. In: A.W. Rose and H. Gundlach (Editors), Geochemical Exploration 1980. Developments in Economic Geology, 15. Elsevier, pp. 271-284.

Nesbitt, H.W., 1979. Mobility and fractionation of REE during weathering of a granodiorite. Nature, 279: 206-210.

Pedro, O. and Bittar, K.E., 1966. Contribution of l'Etude de la genèse des sols hypermagnesiens: recherches experimentales sur l'alteration chimique des roches ultrabasiques (serpentinites). Ann. Agron., 17: 611-657.

Souza, F.A., 1989. Contribuicao ao intemperismo ferralitico de duas regioes do semi-arido da Bahia. Monografia de Mestrado. 1st draft (unpubl.), CPGG/UFBA., 98 pp.

Tardy, Y., 1967. Etude géochimique des eaux d'une nappe d'arene en Pays Cristallin (Korhyoyo, Cote divoire). Bull. Serv. Carte Geol. Alsace Lorraine, 20: 235-256.

Tardy, Y., 1969. Geochimie des alterations. Etude des arenes et des eaux de quelques massifs cristallins d'Europe et d'Afrique. Mem. Serv. Carte Geol. Alsace Lorraine, 20: 255-256.

Teixeira, L.R., 1989. Prospeccao geoquimica de Ouro e Cobre em solo residual da Serra da Baixa do Rancho, Sento Sé, Ba., UFBA., unpubl. master thesis, $86 \mathrm{pp}$.

Tricart, J. and Da Silva, T.C., 1968. Estudos da geomorfologia da Bahia e Sergipe. Imprensa Oficial da Bahia. Salvador, 184 pp. 